Novi Sad

\title{
EDUCATION SYSTEM OF THE KINGDOM OF DENMARK ${ }^{2}$
}

Abstract: From ancient times to the present day, education is a most important factor in the development of humanity. For that reason, a large number of countries invest all available resources in research and improvement of education systems. However, the improvement of education system of a country is not an easy task, and its experts are faced with an extremely important and extensive task. It is especially difficult to implement ideas and methods that have never been implemented before. Putting the idea into action often requires different resources, without necessary guarantee of success. That is why a large number of countries decide to initiate cooperation with other countries in the world, with the aspiration to implement an exchange of knowledge and experiences among experts employed in various education systems, different kinds of analyses of education systems are often created as a result of such meetings and exchanges, which include one or more countries in the world. This way of exchange contributes to a better understanding of the education system of the country, but also to recognizing advantages and disadvantages of different education systems, and finding ways to improve them, as well as space to implement desired components of another country's system. Precisely for these reasons, the aim of the paper is to consider and analyze education system of the Kingdom of Denmark with special reference to systems of preschool, primary, secondary, and higher education.

Keywords: analysis, Denmark, education

\footnotetext{
${ }^{1}$ Ana Vujkov, bogojevana@gmail.com

${ }^{2}$ This paper was created from a master thesis named "Comparative Analysis of Education System of the Kingdom of Denmark and the Republic of Serbia", which was defended in June 2021, at the Department of Pedagogy, Faculty of Philosophy, University in Novi Sad.
} 


\section{INTRODUCTION}

Since the emergence of modern societies to the present day, the education system has played a significant role in their development. That is why a large number of countries in the world invest all available resources in the improvement of the educational system.

A detailed analysis of the education system of a country provides us with a better insight into its functioning, and helps us to see the strengths and weaknesses of that system, its potentials and fields for improvement, and all that contributes to better anticipation of potential obstacles in implementing reforms. By analyzing the system, we can determine all of the above, and also gain an insight into which elements from one system can be applied in another, and thus improve and reform it. The times in which we live are characterized by rapid technological changes and globalization, which impose trends in education, which are often very difficult to follow. However, the age of globalization is also the age of networking, a time of ease and faster access to information, which, in turn, allows us an easier insight into education systems of other countries, as well as an insight into examples of good practice, which is possible to implement. This paper presents an analysis of the education system of the Kingdom of Denmark, their similarities and differences, with special reference to the advantages and disadvantages of this system.

\section{DANISH EDUCATION SYSTEM}

In the Kingdom of Denmark, attending school is mandatory for all children between 7 and 16. At the age of 6 , children attend preparatory preschool class integrated into the school curriculum. Before going to 
school, children often attend preschool institutions that are not mandatory. However, there is always an option for a child to stay either in a private or a state kindergarten. When it comes to the stay of children in private preschool institutions, the state does not bear all the costs, but it can pay subsidies in a certain amount to the institutions where the children stay, for which the local self-government is usually responsible. In this case, the local self-government bears $75 \%$ of the costs, while the parents bear $15 \%$ of the costs of the child's stay in the institution (Ministry of Children and Education, 2020). Children have the right to attend public or private schools, and there is an option of homeschooling, as long as the standards prescribed by the Ministry of Children and Education are respected (UNESCO, 2012). Until 2012, this ministry was called the Ministry of Education, and in 2012, the name was changed to the Ministry of Children and Education.

Parents have the right to choose how and in which school their child will be educated. As for homeschooling, it is not widespread in Denmark, for the simple reason that parents do not choose this way of schooling very often. When it comes to private schools, if parents choose this way of schooling for their child aged 7 to 16 , the state bears $85 \%$ of the costs of education, while parents bear the remaining 15\%. Private schools are in no way discriminated against the state-owned schools, if they meet two conditions. The first condition is that private schools must adhere to the standards prescribed by the state, so that all children who graduate from the private schools have the same chances to continue their education as children who graduate from public schools. The second condition is that teaching must take place in a free and democratic atmosphere, thus 
preparing students for further life (Wachter, 2016). Education in public schools (Folkeskole) is completely free of charge. Grades from the first to the sixth are considered lower grades of primary school, while grades from the seventh to the ninth are considered lower grades of secondary school. Students who complete all nine grades can go to vocational high schools, or choose to complete the tenth grade as well. If the students choose to finish the tenth grade, they usually enroll a general secondary school, which is a preparation for higher education. When it comes to vocational schools, the education is dual, so the theoretical part of teaching takes place at school, while the practical part most often takes place in companies that work in a given field.

Depending on the school curriculum, secondary education usually lasts between three and four years. Afterwards, education continues on a higher level, which includes colleges and universities, bachelor, master, and $\mathrm{PhD}$ programs. (Ministry of Children and Education, 2012). Upon completion of bachelor studies that usually last three years, it is possible to enroll a master's degree program, which duration is two years.

Educational institutions have gained a great autonomy in decisionmaking through the process of decentralization. Goals and standards of education are prescribed by the Ministry, while decisions on the manner of implementation are made by the institution, in cooperation with the local government.

The Danish Ministry of Children and Education has set up several state-level agencies and bodies that provide support and strive to ensure the quality of education. "Danish School Agency" has been created with the 
aim to continuously ensure and provide the quality of the educational system by monitoring the quality of work in preschool and school institutions. The main task of the the "Danish Education Support Agency" is the management of money allocated by the state for education at all levels, with a special focus on expenditure for higher education and scholarships awarded by the state to students. The "Uni. C" agency works to provide technical support to education in Denmark, including the most up-to-date information on the education system, and collect all relevant information that could be useful both to parents and students. This agency also makes various statistical analyses in the field of education (The Danish Ministry of Education, 2010). The Danish Learning Portal (emu.dk) is a website created by the Ministry, which contains all the information necessary for teachers and educators, such as basic instructions for using the site, examples of good practice, literature, necessary materials for work, documentation, and templates for conducting research.

\section{Preschool Education in the Kingdom of Denmark}

Preschool education is the first step in a child's education in the Kingdom of Denmark. Attendance at a preschool is not mandatory, until the child reaches the age of six, when he/she starts the preparatory preschool class, attended at school. However, a large number of children attend the preschool in Denmark.

Preschool education is under the jurisdiction of the Ministry of Social Affairs and Integration, and the local self-government of each place is obliged to provide a sufficient number of places in preschool institutions. Parents can choose to enroll their child either in a state or a private 
preschool. Those parents whose children attend the state kindergarten pay a monthly allowance for the child's stay in the amount which is most often determined in accordance with the amount of total household income. As for private preschools, some local governments pay $75 \%$ of the total price for a child's stay in the institution on a monthly basis, while $15 \%$ of the total costs are paid by the parents. However, this depends on the local government itself and does not apply to all places equally. State kindergartens include nurseries (vuggestuer) for children aged three, and kindergartens (børnehave) for children aged three to six. The preparatory preschool classes, as stated, are attended by children aged six. The working hours of preschool institutions are usually from 6:30 or 7:00 hrs in the morning, until 17:00 hrs in the afternoon, form Monday to Friday.

The educators in Danish kindergartens must complete bachelor studies in the field of education, as well as internships. Every preschool institution independently adopts a curriculum that should contain information on the space provided for working with children, a description of activities to be carried out with children in the areas prescribed by the Ministry, concerning child personality development, social competencies, speech development, physical health, development of moral values and artistic expression (UNESCO, 2012). It is interesting that preschool institutions have not always had the obligation to adhere to these areas. Until 2004, when the results of PISA testing showed that students achieved below average results, numerous changes were introduced, including the introduction of mandatory areas within which it was necessary to organize the activities in preschool institutions (OECD, 2020). Staff can independently choose the methods and techniques of work, as well as 
necessary materials. However, it is important that the activities follow the framework given in the curriculum, and that they are implemented in such a way that they belong to one of the mentioned areas. Also, preschool institutions have a legal obligation for the activities to be in line with topics that contribute to children's well-being, health and development, creating an atmosphere of support that contributes to the development of children's selfconfidence and independence. The focus is also on the development of social skills, and on the fact that the institution is obliged to provide the child with the easiest possible transition from preschool to school environment, in cooperation with parents (UNESCO, 2012). It is also important that children feel as a part of the community, so a large number of activities are organized in cooperation with the local community. The integration of children with special needs is a very important part of preschool education, and a lot of attention is paid to this. Children with special needs are entitled to additional help and support, which is most often reflected in the employment of additional staff.

It is also an interesting fact that parents in Denmark very often opt for nannies who take care of their children in their own homes, while the parents are at work. These occupations are regulated by the Danish law, and nannies have an obligation to adhere to the curriculum developed for them by the local self-government. If they want a nanny, parents have the opportunity to ask the local government for a person to look after their child, or to hire a nanny through some other institutions.

Kindergartens in nature are also a very common phenomenon in Denmark. There are different models of such kindergartens. For example, there are kindergartens which facilities are located in the cities, and do not 
have a yard. In this case, children, together with the educators, use a kind of transport to go to nature. Although the facility is not located in nature, children spend most of the day outside. Another type of such kindergartens is the kindergarten which facilities are located in nature. In this case, the place where the kindergarten is located is an integral part of daily activities performed outside or inside the kindergarten. Thus, children explore flora and fauna outside, or an element of it can be introduced inside, where the research will continue (Wiliams-Siegfredsen, 2017). Natural materials are used every day, and children in these kindergartens learn independence, as well as the use of various tools for processing materials. Children in Danish kindergartens stay outside even when it is cold or raining. When enrolling, parents bring necessary clothes (raincoats, jackets, and boots) for children to wear when it is cold. Although these kindergartens are most often attended by children older than three, workshops for younger children are often organized (Muhic, 2020).

Preschool education in Denmark has its roots in the pedagogical understandings of Rousseau, Pestalozzi, and Frebel, and it was greatly influenced by critical theories during the twentieth century. These approaches imply a focus on the child, his/her holistic development, and emphasize the importance of activities and play, as well as the rich environment in which the child develops. In the Danish system, the educator has a supporting role, as well as the task to recognize and satisfy the child's needs. Great importance is attached to Peer relationships are also very important. 


\section{Compulsory Preschool and Primary Education in the Kingdom of Denmark}

Compulsory preschool and primary education in the Kingdom of Denmark consists of a preparatory preschool classes attended by children aged six (the so-called "year zero"), and there are nine classes of compulsory schooling. The obligation to attend the preparatory preschool classes was introduced in 2010. The tenth grade is not mandatory, but if they want, students can choose to attend it. Public schools are free of charge for all students, but parents can also enroll a child in a private school, where the child's stay is partly financed by the state and partly by parents (Ministry of Children and Education, 2012).

In preparatory classes, the greatest focus is on learning through play. Children learn about various topics through different games, such as language, nature and its phenomena, practical and musical skills, communication and social skills. The curriculum is made separately for each student who attends school from the preparatory to the seventh grade. The curriculum and the plan for further education are created for students attending the eighth and the ninth grade. This helps students very much, when it comes to directing their interests (The Danish Ministry of Education, 2010).

Some of the goals important to achieve when education of children in the Kingdom of Denmark is in question, are the following: to provide children with knowledge and skills that will prepare them for further learning, awaken their desire for knowledge, introduce them to the culture and history of the country in which they live, but also to other countries in the world, contribute to the building of positive relations of the child with 
other living beings and nature, and finally, contribute to the overall development of the child's personality. It is necessary to create an atmosphere in which children will have an opportunity to explore and discover the world around them, which will help them to develop selfconfidence and awareness of their own abilities, enabling them to cooperate and have awareness of shared responsibility and human rights, and preparing them for living in a democratic society (UNESCO, 2012).

Subjects at school are divided into three groups:

1. Humanities, which include the following subjects: Danish language (attended from the third to the ninth grade), English language (from the third to the ninth grade), Christianity and History (from the third to the ninth grade), and Human Studies (from the eighth to the ninth grade).

2. The group of practical and creative subjects includes: Physical Education (from the first to the ninth grade), Music (also from the third to the ninth grade), Visual Arts (from the third to the fifth grade), while the subject Design and Work with wood, metal, and home economics can be attended for one or more years, from the fourth to the seventh grade, depending on a students' choice.

3. Natural sciences, which include the following subjects: Mathematics (from the first to the ninth grade), Technology (from the first to the sixth grade), Geography (from the seventh to the ninth grade), Biology (from the seventh to the ninth grade), Physics, and Chemistry (from the seventh to the ninth grade).

In addition to these subjects, mandatory topics covered during schooling are: traffic safety, health, sexual and family education, and 
professional orientation. Other foreign languages (German or French) are subjects offered as electives to students attending the seventh, the eighth, and the ninth grade, as subjects required for the high school enrollment.

Danish as a foreign language is offered to students who need it during the period of preschool education and through the period from the first to the ninth grade. The opportunity to choose the subjects according to their interests is given to students from the eight to the ninth grade. Information technology is an integral part of primary education. It $t$ is integrated into almost every subject, and can be studied within three elective subjects. As for the subject of Christianity, it is studied from the angle of the Evangelical Lutheran Church. Other religions are studied at higher levels of education. Children may be excluded from studying this subject at the request of a parent/guardian if he or she undertakes to take care of the child's religious education on his/her own (UNESCO, 2012).

Primary school teachers must complete their master studies and one year of practice in order to be able to work, while pedagogical assistants undergo training in the field of pedagogical assistance.

During schooling, students undergo various tests in certain subjects. For example, at the end of the second, the fourth, the sixth and the eighth grade, students take a Danish language test with a focus on reading. Mathematics is tested at the end of the third and sixth grade. English language is tested at the end of the seventh grade, while Geography, Biology, Physics, and Chemistry are tested at the end of the eighth grade. These tests were introduced as mandatory in 2010, after many years of consideration. Upon completion of the ninth grade, students take a test in 
seven subjects, five of which are compulsory for all, and two subjects are selected at random. Also, they need to make and present a mandatory interdisciplinary project. Upon a successful completion of testing and presenting the project, students receive certificates that confirm their knowledge and ability for further education (UNESCO, 2012).

If they decide to attend the tenth year of primary school, it can be organized as a program that lasts the whole year or the school year can be shortened. The tenth grade consists of several compulsory subjects (English, Danish and Mathematics), which occupy half of the curriculum studied during the school year. The other half of the curriculum is occupied by elective subjects, and the school year is organized according to the student's interests and the curriculum created by the student during the ninth year. Students also participate in the curriculum that helps them transition from the compulsory education system to the secondary education system, pointing out the importance of continuing their education. At the end of the tenth grade, students can be tested in several subjects, the most common of which are Danish, English, Mathematics, German or French, and Physics or Chemistry. Also, students can choose to take a test from one of the subjects from the ninth grade, or to combine subjects from the ninth and the tenth grade (UNESCO, 2012). The Law on Primary Education of the Kingdom of Denmark emphasizes the importance of adapting the learning process to students' needs, enabling the organization of teaching by "merging" classes or dividing students into groups. Individual teaching is allowed in exceptional cases. If this way of teaching does not meet the needs of a student, he/she is provided with additional support and assistance in the form of additional classes in subjects in which he/she has difficulties. In 
special cases, a student may be transferred to another class or a school adapted for students with special needs. There is also an option of organizing classes differently, so that the student attends regular classes, and then gets additional classes in another school, where he/she could get additional help. Special classes are held for students with intellectual disabilities, dyslexia, vision problems, hearing problems or some kind of physical disability. In principle, expectations of students with special needs who attend regular classes are not reduced compared to other students, but they are provided with additional support in the form of special classes, consultations and personal assistants (UNESCO, 2012).

When it comes to grading, students are most often graded descriptively, through year-end testing and at the end of compulsory schooling. Students usually move on to the next grade easily, and repetition of the grade is very rare. Students attending grades from preparatory to the seventh grade and their parents are regularly informed about the student's progress by teachers and the school management. This information is usually given twice a year at parent-teacher meetings, where they discuss the rules of conduct within the school and in the classroom. Older students, those attending the eighth and the ninth grade, are graded twice a year, by using a specially designed, seven-point grading scale. Grade -3 means that the work is completely unacceptable, grade 00 evaluates students who has not met not meet the minimum criteria, grade 02 evaluates students who meet only the minimum criteria, while grade 4 implies sufficient achievement and knowledge from which it can be seen that the student masters the matter, but also shows some weaknesses. Grade 7 shows good achievement and mastery of the matter, but also indicates that there is room 
for improvement. Grade 10 indicates very good achievement and mastery of the matter with only few negligible errors, and grade 12 indicates excellent achievement and high mastery of the matter without any or with few negligible errors. Also, at the end of the ninth grade, students are given a grade after completing the project and its presentation (UNESCO, 2012).

According to OECD reports in 2018, it is important to note that, 15year-old students in Denmark scored above average in PISA (Program for International Student Assessment) in reading and comprehension, mathematics and science. Regarding the reports on the work of schools and the way students perceive them, students in Denmark have stated that they feel a great sense of belonging to the school, which has been measured above average. They have also stated that they feel like they receive more support from teachers than average. Teachers have stated that they have a great sense of confidence and readiness to work. The level of peer violence in schools is also lower than average. However, the problem observed by the OECD is the fact that children from migrant families have significantly lower achievements compared to their peers who were born and raised in Denmark. Therefore, OECD has, made a number of proposals to support the children of immigrants. Shortly before this study, the Kingdom of Denmark has also enacted provisions to improve the situation of young immigrants (OECD, 2020).

Secondary education in the Kingdom of Denmark

Where students will go after primary school depends on their interests. Secondary education in Denmark can be divided into secondary vocational education, which provides students with the knowledge and skills 
necessary for practical work, and higher secondary education, which provides students with necessary knowledge to enroll college. As with primary schools, there are public and private secondary schools.

The students who have completed nine years of primary education can opt for secondary vocational schools, which train them for their future profession, and also for other types of programs that are offered as well.

Vocational high schools include professions in the fields of commercial, technology, social and health care, and agriculture. They usually offer twelve basic courses that provide prior knowledge for courses at colleges, for which students can, but do not have to, opt later. Therefore, they can provide a good basis for further studies, if students are interested in it. Basic courses are attended for three to four years and these schools belong to the dual education system. Accordingly, students take half of the courses in the classrooms, while the other half of students are done practically, at work, in one of the organizations that operate in the field of students' interest. It is important to note that, like most schools in Denmark, these schools have great autonomy and are free to organize their curricula according to the capabilities and needs of the local community, which is very desirable. This system is very flexible and the curricula are adapted to the students, which means that there are different options and ways in which students can schedule their time at school and at work. Students often get employed by the companies and receive financial compensation for their work. At the end of the program, students must successfully pass both the theoretical and practical part of the test, in order to receive certificates of completion of schooling (UNESCO, 2012). 
As for other secondary education programs, there are four different programs, aimed at preparing students for enrollment. These programs are the following: gymnasiums (STX program), higher preparatory program (HF program),higher commercial program (HHX program) and higher technical program (HTX program). The goal of these institutions is to prepare students for enrollment in college and help them gather as much necessary knowledge as possible. These abbreviations, which are used as program names, actually represent the names of the final exam that is taken at the end of the program.

Gymnasium programs usually last up to three years and are quite extensive. They include social and natural sciences, and can be enrolled by the students who have completed the ninth grade, as well as by those who have completed the additional, tenth grade. This program is most similar to the one at the faculties and does not contain a practical part. In addition to several compulsory subjects, these schools offer students a large number of elective programs and subjects which are in line with their interests, and most strive to develop students' independence, cooperation, and ability to think critically.

A very interesting fact is that the subjects in gymnasiums are divided by levels (A, B and C level), which refer to higher (A), intermediate (B) and basic (C) level. Every student is required to master Danish (A level), English (B level) and another foreign language at A or B level. History must be mastered at the A level, and the studies of Antiquity, Physics, Sports, Art, Mathematics, Religion and Social Sciences are subjects from which a minimum $\mathrm{C}$ level is required. Also, one of the following subjects: Biology, Geography, and Chemistry, must be chosen by a student at the C level. In 
addition to these, electives also include Visual Arts, Media, Music and many others. When it comes to another foreign language, students can choose among German, French, Spanish, Russian, Italian, and Chinese. Also, students should choose subjects that are offered, which are in line with their future profession and the program in which they want to study. It is important to note that the offer of elective subjects can vary from school to school, which means that not every high school has the same offer of elective subjects. In class, students are actively involved in discussions and debates, as well as in solving problem tasks. They are also engaged in various projects. At the end of schooling, every student has the task to write and defend a thesis that combines several fields of his/her interest. When it comes to grades, the same seven-point scale is used as in primary school (Gymnasieskolernes Rektorforening, 2013).

The higher preparatory program does not differ much from gymnasium, except in duration. These programs last for two years and include subjects that are included in gymnasium. They are also mastered according to A, B or C level. At the end of the second year, students must pass an oral and written exam covering several different disciplines they have studied. What distinguishes this program from gymnasium are the mandatory workshops that are present in the first and the second year, as well as the method of work consisting of group and project activities, homework, and online teaching.

Higher commercial programs that are mainly offered by colleges are focused on business and economics, marketing and international economics, with a special focus on foreign languages. These schools offer initial training with three months duration, followed by a program of students' 
choice, which duration is two years and five months. Schools offer thirteen different programs of economic orientation from which the student has the right to choose. The basic program, which duration is three months, contains the following subjects: Danish, English, Mathematics, and Social Sciences, as well as two subjects from the course in which the student is interested. In addition, this program includes a basic course in economics, a basic foreign language course and elective courses. The specialized study programs that the students can choose after these three months contain subjects of $\mathrm{A}, \mathrm{B}$, and C level. Students are required to master Danish and English at A level, another foreign language at A or B level depending on whether they have studied it before or not, Business and International Economics, Marketing, History, and Mathematics at B level, and Business Law and Social Sciences at $\mathrm{C}$ level. As for the final project, it is similar to other schools: the student is obliged to make and present a project based on minimum two subjects that he/she has mastered at the A level. While making the project, the student is under the supervision of the professor (The Ministry of Children and Education, 2019).

Higher technical program is focused on the fields of technology, natural sciences, and informatics. Students learn both through theory and practice, and the practical part takes place in laboratories. Like higher commercial programs, technical programs offer initial training which duration is three months, after which students choose from eighteen specialized programs. Higher technical programs are mainly offered by technical faculties and faculties of natural sciences. The basic course consists of Danish, English, Mathematics, Social Sciences, and subjects from a specialized program. In addition, it contains a basic course in product 
development, a basic course in natural sciences and elective courses. The specialized program offers compulsory courses arranged according to A, B, and $\mathrm{C}$ levels, as well as courses from the specialized program, elective courses, and an individual project. Danish language and technical sciences need to be mastered at A level, English, Physics, Mathematics, Technology, Chemistry, and History at B level, while Biology, Informatics and Social Sciences at $\mathrm{C}$ level. As in other schools, the individual project is made in the final year, and students of technical programs should cover six different fields of the project. The student works on the project independently, under the supervision of the professor, and finally defends it orally. These schools mostly base their teaching on experiments and practical tests of assumptions.

\section{Higher education in the Kingdom of Denmark}

Every student who has passed one of the final exams -STX, $H F$, $H H X$ or $H T X$-at the end of high school has the right to higher education in Denmark. If a student has attended a vocational high school for four years, he or she may also be able to attend higher education. Some faculties and colleges may have additional enrollment criteria, such as a high grade in certain subjects in high school or levels of mastery in a particular subject during high school, all of which depend on the institution. The most common additional criteria when enrolling is a high level of knowledge of the English language, which is a requirement that applies both to foreign citizens and Danish students.

Institutions that provide higher education in Denmark are colleges and universities. There are also different types of institutions that provide 
higher education: seminarium (special institutions for the education of future teachers), højskole (institution for the education of social workers, journalists, and some types of engineers), and skoler (institutions for the education of physiotherapists and laboratory technicians). There are eleven universities and one hundred and twenty higher education institutions in Denmark. Higher education is mostly financed from the state budget, while students pay for specialist courses or some other types of additional courses they attend. The head of the institution is the dean, or the rector, and the advisory role is mostly played by local representatives of employers. It is important to note that Denmark is a country of the European Union with a very dense network of higher education institutions that have a great support from the government and local employers and companies, so that in almost every city in Denmark there is some kind of higher education institution. The political goal of the Government of the Kingdom of Denmark is for $50 \%$ of the young people to complete some form of higher education in their country. This percentage is currently around 39\% (Havelka, 2003).

Studies in Denmark can last up to two and a half years, three to four years or five or more years. If the student opts for studies which duration is two and a half years, he/she receives an academic degree and acquire practical knowledge and skills, which are most often related to the fields of information technology, economics, and management. These studies are equivalent to 120 ECTS. Universities offer undergraduate academic studies which usual duration is between three and four years, and which are equivalent between 180 and 270 ECTS.

The number of points can vary depending on which studies are in question at which faculty. For example, duration of bachelor studies in 
pharmacy is between five and six years, duration of architecture is five and a half to six years, and duration of bachelor studies in medicine, dentistry, and veterinary medicine is between five and a half and six and a half years. Duration of Master academic studies is two years, and they are equivalent to 120 ECTS, and the diploma is obtained after the defense of the master's thesis. Duration of Doctoral studies is usually three years, including six months of initial training for the research work and the defense of the dissertation itself.

Courses at colleges in Denmark are interactive, students are mostly involved in debates, and the forms of work used are pair work and group work. In addition to debate, teaching methods include traditional, ex catedra teaching that is combined with a project-based approach to learning and project work with the help of teachers. Most faculties also often opt for a combination of lectures and workshops in small groups. Attendance is rarely scored, as are per-examination activities. Higher education institutions also use the seven-point grading scale used in primary and secondary schools (Agerbæk, 2017).

Faculties often offer several departments, and in the building itself you can find research laboratories with all the necessary equipment, research centers, study spaces, libraries, and canteens. The faculty buildings are not located within the campus and are not physically separated from the city nor are they all in the same place. They are often distributed in more urban parts of the city, functioning as an integral part of it. "Student houses" are places run by student volunteers, and they are similar to cafes and learning spaces or concerts, where students gather. 
The faculty buildings, libraries, and study spaces are accessible to students, as well as literature. Students also have access to literature in electronic format. As for accommodation, students have access to student dormitories provided by the city in which the faculty is located and if they get it, they are provided with a place during their studies. However, waiting lists for places are very long, and therefore most students opt for private accommodation (Agerbæk, 2017).

The faculties also have many active support networks and mentoring programs which students can join, where they will find help from older colleagues, and gain new acquaintances. Also, a large number of students in Denmark are involved voluntarily in a number of organizations and activities, which can be organized either by the faculty or by other organizations. A large number of faculties also have different sections that students can join, such as a choir or drama section (Agerbæk, 2017).

As far as employment is concerned, students from the Nordic countries, EU countries, and Switzerland have the right to work an unlimited number of hours during their studies. When it comes to students from outside these countries, they are entitled to work for 20 hours during the working week, and to full-time work during June, July, and August. Also, students who are residents of Denmark and EU countries are entitled to student scholarships, while those who are outside this framework are not entitled to the scholarship (Agerbæk, 2017). 


\section{CONCLUSION}

Evaluation of education systems of other countries of the world and their analysis gives us a clearer picture of them, which helps us to see their strengths, weaknesses, obstacles, and opportunities for their improvement.

As we said at the beginning, every country has its own qualities when it comes to education. Speaking of Denmark, there are many innovations that could be applied in other systems. For example, the fact that children in Denmark spend a great amount of time outdoors is definitely something that could be applied to other education systems. Kindergarten teachers have a certain amount of freedom, when it comes to deciding which program they want to base their work on. Also, the use of technology in elementary and high schools is very intensive and that is something that is very commendable. When it comes to colleges and universities, it is very important to note that all students from the European Union can be scholarship holders if they decide to study in Denmark.

Analysis like this one is very important for experts who actively reform education systems all over the world. Reforming the education system of a country is not an easy task, and it requires exceptional skills and great dedication from its experts. Due to the fact that the implementation of an idea at the level of the entire system of upbringing and education requires a lot of material and human resources, and often does not guarantee success, experts from many countries around the world often wonder where to begin with reformation. Papers like this one could help them to easily find and apply some of the changes that other countries have already successfully applied. 


\section{OBRAZOVNI SISTEM KRALJEVINE DANSKE}

\section{Apstrakt}

Od davnina, pa sve do danas, vaspitanje i obrazovanje predstavljaju značajan faktor razvoja ljudskog društva. Veliki broj država iz tog razloga ulaže sve dostupne resurse $\mathrm{u}$ istraživanje $\mathrm{i}$ unapređivanje vaspitno-obrazovnih sistema. Ipak, unapređenje vaspitno-obrazovnog sistema jedne države nije ni malo lak posao i pred njene stručnjake postavlja se izuzetno važan i obiman zadatak. Posebno je teško implementirati ideje i metode koje nikada ranije nisu bile implementirane, a sprovođenje zamišljenog u delo često iziskuje različite resurse, bez nužne garancije za uspeh. Upravo zato veliki broj zemalja odlučuje se na pokretanje saradnje sa drugim državama u svetu u želji da se ostvari razmena znanja i iskustava između stručnjaka zaposlenih u različitim vaspitno-obrazovnim sistemima. Neretko, kao rezultat ovakvih susreta i razmena, nastaju i komparativne analize vaspitnoobrazovnih sistema koje uključuju dve ili više zemalja u svetu. Ovakav način razmene doprinosi boljem razumevanju vaspitno-obrazovnog sistema matične $\mathrm{i}$ strane zemlje, ali i uviđanju prednosti i mana različitih obrazovnih sistema i pronalaženju načina za njihovo unapređivanje, kao i prostora za implementaciju željenih komponenti sistema druge zemlje. Upravo iz ovih razloga, cilj rada je sagledavanje sistema vaspitanja i obrazovanja Kraljevine Danske sa posebnim osvrtom na prednosti i mane vaspitno-obrazovna sistema.

Ključne reči: analiza, Danska, obrazovanje 


\section{REFERENCES}

Agerbaek, S. (2017). International students' survival guide to life in Denmark. Copenhnagen: Copenhagen Business School.

Gymnasieskolernes Rektorforening (2013). The "Gymnasium"- A Danish upper secondary education. Copenhagen: Gymnasieskolernes Rektorforening.

Havelka, M. (2003). Visoko obrazovanje u Hrvatskoj i europskim zemljama. Zagreb: Institut društvenih znanosti Ivo Pilar.

Ministry of children and education (2019). København: The Danish Ministry of Education. Retrieved 20. 03. 2019 from: https://eng.uvm.dk/upper-secondary-education/national-uppersecondary-education-programmes/the-higher-preparatoryexamination--hf-

Muhic, A. (2020). Primjena šumske pedagogije u vrtiću, Diplomski rad. Pula: Sveučilište Jurja Dobre u Puli.

OECD (2020). Education policy outlook: Denmark. Paris: OECD Publishing

OECD (2018). Denmark: Country Note - PISA 2018. Paris: OECD Publishing.

The Danish ministry of education (2010). Welcome to the Danish Folkeskole. København: Danish Ministry of Education.

The Ministry of children and education (2012). Education and training in Denmark. København: Ministry of Children and Education.

The Ministry of children and education. (2020). København: The Danish Ministry of Education. Retrieved 09. 01. 2020 from the Web site:https://eng.uvm.dk/general-overview/overview-of-the-danisheducation-system

The Ministry of children and education (2019). København: The Danish Ministry of Education. Retrieved 20. 03. 2019 from the Web site: https://eng.uvm.dk/upper-secondary-education/national-uppersecondary-education-programmes/the-higher-preparatoryexamination--hf- 
UNESCO, IBoE. (2012). World data on education principles and general objectives of education. Paris: UNESCO.

Wachter, T. (2016). AT, SRO und SRP: Eine Untersuchung des dänisches Schulwesens mit Fokus auf Mathematik als Bestandteil fächerübergreifender Maßnahmen, Masterarbeit, Graz: KarlFranzens-Universität.

Wiliams-Siegfresend, J. (2017). The Danish forest school approach. In: Early Horizon Magazine, 6(1). Australia: ASG Publishing. 